\title{
Multimarket Bank Pricing: An Empirical Investigation of Deposit Interest Rates
}

\author{
by \\ Timothy H. Hannan and Robin A. Prager \\ Board of Governors of the Federal Reserve System \\ Washington, DC 20551
}

June 8, 2004

The views expressed in this paper are those of the authors and do not necessarily reflect the views of the Board of Governors or its staff. Onka Tenkean provided outstanding research assistance on this project. 


\begin{abstract}
In recent years, the number of large, geographically diversified banking organizations operating in the U.S. has grown. Empirical studies have found that, at least in the case of deposit interest rates, many of these banks offer the same rate for a given type of account throughout a state, or, in some cases, a broader geographical area. This phenomenon of uniform pricing raises questions as to what competitive factors are relevant in explaining the deposit interest rates offered by large multimarket banks. In this paper, we provide empirical evidence regarding the determinants of the deposit interest rates offered by these banking organizations.
\end{abstract}




\section{Introduction}

Recent years have witnessed important changes in the U.S. banking industry. Deregulation has removed many of the previously existing geographic constraints on banking organizations, allowing banks to establish branches across numerous local areas within states and even across state lines and throughout the country. Thus, increasingly, large banking organizations in the U.S. are spreading out over a larger number of the areas typically defined as local banking markets in regulatory analyses, obtaining smaller and smaller shares of their deposit base from any one of them. ${ }^{1}$ At the same time, the majority of U.S. banks continue to operate primarily within the confines of a single local banking market.

As the number of large, geographically diverse banking organizations has grown, their share of nationwide deposits and the number of local banking markets in which they operate have grown as well. These developments have prompted researchers to consider the effects of multimarket bank branching on the nature of competition in retail banking markets.

A considerable body of evidence suggests that, at least in the case of deposit interest rates, many geographically diversified banks offer the same rate for a given type of account throughout a state, or, in some cases, a broader geographical area. This phenomenon of uniform pricing raises questions as to what competitive factors are

\footnotetext{
${ }^{1}$ In many other countries, large banking organizations that operate in numerous local areas have dominated the scene for some time.
} 
relevant in explaining the deposit rates offered by large multimarket banks. One possibility is that multimarket banks perceive retail banking markets to be local in their geographic extent, but choose to set prices that do not vary across local areas within a state or larger region. Such price uniformity might be optimal if the costs of establishing and maintaining different prices in many local areas exceed the benefits. In this case, the uniform price would be expected to reflect a weighted average of local market conditions in the markets in which the bank operates.

Alternatively, large, geographically diversified banks may view themselves as operating in geographic markets that are substantially broader than those areas traditionally defined as local markets. In this case, they would be expected to establish prices on the basis of conditions that apply to this broader geographic area.

Another issue regarding the deposit pricing of large banking organizations concerns the possibility that they have access to cheaper wholesale sources of funds than do smaller institutions. Several studies have reported that large banking organizations typically offer lower deposit rates and charge higher deposit-related fees than do smaller banking organizations. There is also some evidence that they charge lower interest rates for many types of loans. Several recent contributors to the literature have speculated that these differences may reflect access to cheaper wholesale funds on the part of larger organizations.

In this paper, we seek to explain the deposit interest rates offered by large, multimarket banks in a way that takes into account these potentially important 
determinants. Using deposit interest rate measures constructed from bank-level accounting data for a large cross-sectional sample of banks for each of three different years, we estimate three alternative models of deposit rate determination. We find strong evidence that large banks, or banks that are part of large banking organizations, offer lower deposit interest rates than their smaller counterparts. Our findings regarding the relationships between deposit interest rates and weighted averages of local versus state level conditions are somewhat mixed; however, we do find that for the multimarket banks in our sample, state level concentration is more strongly and consistently related to deposit interest rates than is a weighted average of local market concentration. Also of interest, we find strong evidence that, even after controlling for the size of the organization, banks that operate in a larger number of local banking markets offer lower deposit interest rates than those operating in fewer markets.

The plan of the paper is as follows: Section 2 reviews the relevant literature and section 3 presents the empirical model. The sample and data are described in section 4, and empirical results are presented in section 5. A final section discusses conclusions and policy implications.

\section{The Literature}

Several recent studies examine the pricing behavior of large, multimarket banks and consider the implications of that behavior for the geographic scope of retail banking markets. Radecki (1998) documents that large multimarket banks typically quote the same 
interest rate for a particular type of deposit account in different metropolitan statistical areas (MSAs) within the same state. He concludes that "local markets the size of a single county or metropolitan area are no longer relevant and that state boundaries may offer a better approximation of the boundaries of retail banking markets" (p. 16). Heitfield (1999) confirms Radecki's finding of uniform pricing within a state by multimarket banks, but notes that this finding does not imply expanded geographic markets, since the deposit interest rates offered by single-market banks vary substantially across cities within a state.

Biehl (2002) reports pricing patterns among banks operating in metropolitan markets within New York state that seem to indicate that deposit interest rates offered by single-market banks reflect local market conditions, while those offered by multimarket banks do not. Biehl also finds that multimarket banks offer lower deposit interest rates, on average, than do single-market banks.

In a study that considers the effect of the presence of multimarket banks on the deposit interest rates offered by single market banks operating in the same local market, Hannan and Prager (forthcoming) report two findings that are relevant to multimarket bank pricing. These findings are: (1) single-market banks tend to offer higher deposit interest rates than do multimarket banks in the same local market, and (2) the deposit interest rates offered by single-market banks are lower, the greater the presence of multimarket banks in their local market. This second finding casts doubt upon a commonly offered explanation for the first - that large multimarket banks can offer lower deposit rates because they provide higher quality service - since it does not seem plausible 
that single-market banks would offer lower deposit rates in response to higher quality service being provided by their multimarket rivals.

Hannan and Prager (forthcoming) speculate that these findings may reflect the fact that large banks have greater access to wholesale funds that are, beyond some point, cheaper than retail sources of funds. This would imply that larger banks do not need to offer as high a retail deposit rate as do small banks, and that smaller, single-market banks would tend to offer lower deposit rates, the greater the presence of such large multimarket banks in their local areas. This explanation is consistent with the findings of Kiser (2004) in a paper that explicitly models the relationship between the cost of wholesale funds and the interest rate offered on retail deposit accounts.

Park and Pennacchi (2003) develop a detailed spatial model of bank pricing in which they assume that multimarket banks set uniform prices across the markets they serve and that these institutions have a funding advantage relative to smaller, singlemarket banks. Their model also assumes that competition among banks takes place at the local market level. Since, in their model, a multimarket bank is constrained to offer the same deposit interest rate everywhere it operates, the rate it offers reflects a weighted average of the conditions prevailing in the local markets in which it operates. The assumed funding advantage leads the multimarket bank to offer a uniform rate that is lower than that which would be offered in the absence of the funding advantage.

The Park and Pennacchi (2003) model implies that, in the most competitive markets, the rates offered by large multimarket banks are lower than those offered by 
single-market banks; the deposit interest rates offered by large multimarket banks may also be lower than those offered by single-market banks in the least competitive markets, if their funding advantage is sufficiently large. In Park and Pennacchi's model, as in the spatial model used by Hannan and Prager (forthcoming), the presence of large multimarket banks offering lower deposit interest rates puts downward pressure on the rates offered by single-market banks operating in the same local markets. Thus, the deposit rates of singlemarket banks tend to be lower, the larger the number or importance of large multimarket banks in the local market.

Park and Pennacchi (2003) draw similar implications for the loan side, where the funding advantage of large multimarket banks is argued to exert a downward pressure on loan rates as well. Thus, while the presence of large multimarket banks in the market tends to hurt the retail depositor, it is beneficial to the loan customer. Because our interest is in explaining deposit interest rates, we do not review those implications in detail.

\section{The Determinants of the Deposit Rates of Multimarket Banks}

In this paper, we investigate the determinants of the deposit interest rates offered by geographically diversified or multimarket banks. This analysis is complementary to that in Hannan and Prager (forthcoming), which focuses on explaining the deposit interest rates offered by banks that operate predominantly within a single local market. As discussed above, multimarket banks may differ from single-market banks both in terms of the competitive factors that influence their pricing decisions and in terms of their access to 
cheaper wholesale sources of funds. Our empirical analysis aims to shed light on the roles that these differences play in determining the deposit interest rates offered by multimarket banks.

We consider three alternative models of deposit interest rate determination. In the first model, the deposit interest rates offered by multimarket banks reflect a weighted average of conditions prevailing in the local areas served by the bank. In the second model, the deposit interest rates offered by multimarket banks are influenced by statewide, rather than local, conditions. We also consider a "hybrid" model, in which both state and local factors influence the pricing decisions of the multimarket firm. In each case, variables reflecting the size of the banking organization and the extent of the bank's geographic diversity are also included. The former serves as a proxy for the firm's access to cheaper, wholesale sources of funds, while the latter captures any advantages or disadvantages associated with wider geographic coverage. Our empirical approach consists of estimating relationships of the form:

$$
\begin{aligned}
& r_{i}^{m m}=\beta_{0}+\beta_{1} \text { very_big }+\beta_{2} \text { big }_{i}+\beta_{3} \ln \left(\text { num } m_{-} m k t_{i}\right) \\
& +\beta_{4} \text { conc }_{i}+\beta_{5} \ln \left(\text { pop }_{i}\right)+\beta_{6} \text { bigshare }_{i}+u_{i}
\end{aligned}
$$

where 
$r_{i}^{m m} \quad$ is a measure of the interest rate offered by multimarket bank $i$ on a particular type of deposit account;

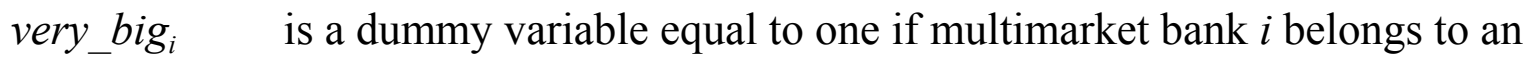
organization with more than $\$ 5$ billion in banking assets;

$\operatorname{big}_{i} \quad$ is a dummy variable equal to one if multimarket bank $i$ belongs to an organization with between $\$ 1$ billion and $\$ 5$ billion in banking assets;

$\ln \left(n u m_{-} m k t_{i}\right) \quad$ denotes the natural logarithm of the number of local markets in which bank $i$ operates;

conc $_{i} \quad$ denotes a weighted average of the Herfindahl-Hirschmann index of concentration for the local markets (states) in which bank $i$ operates, where the weights are the fraction of bank $i$ 's deposits held in each market (state);

$\ln \left(\right.$ pop $\left._{i}\right) \quad$ denotes a weighted average of the natural logarithms of the populations of the local markets (states) in which bank $i$ operates, where the weights are the fraction of bank $i$ 's deposits held in each market (state);

bigshare $_{i} \quad$ denotes a weighted average of the shares of local market (state) branches accounted for by banks that are part of very large ( $>\$ 5$ billion in banking assets) organizations, where the weights are the fraction of bank $i$ 's deposits held in each market (state);

$u_{i} \quad$ denotes a random error term, assumed to be iid.

The variables very $b_{-} g_{i}$ and $b i g_{i}$ are included to proxy for any funding advantage that multimarket bank $i$ might enjoy as a result of the size of the organization to which it 
belongs. We employ the two dummy variables, rather than a continuous measure of size, because we expect that access to cheaper sources of wholesale funds is likely to be relevant only for firms that exceed some critical size threshold. ${ }^{2}$ We use organization size, rather than bank size, to define these variables because the bank holding companies to which (some) banks belong are the entities that typically access wholesale sources of funds. ${ }^{3}$ We expect the coefficients on these two size variables to be negative, to the extent that they reflect a funding advantage on the part of banks that belong to large organizations.

The variable $\ln \left(\right.$ num_$\left.\__{-} k t_{i}\right)$ is included to test for any systematic difference that may be associated with the number of local markets in which multimarket banks operate. Among other things, this allows us to distinguish between effects that are associated with bank or organization size and those that might be associated with the number of local markets in which the bank has a presence. We have no prediction concerning the sign of the coefficient of this variable, but we do offer some ex post rationales for the consistently negative and statistically significant results that we obtain.

The variables conc $_{i}$, pop $_{i}$ and bigshare ${ }_{i}$ are measured at both the local market and the state levels. The local market measures are included to test the hypothesis that multimarket banks price according to a weighted average of the conditions existing in the local markets in which they operate. The finding of a negative coefficient on the local

${ }^{2}$ Using a continuous measure of organization size yields comparable results.

${ }^{3}$ For independent banks, the organization is the same as the bank. 
market concentration variable would be consistent with the joint hypotheses that banks in more concentrated markets offer lower deposit interest rates, as predicted by the structureconduct-performance (SCP) paradigm, and that banks operating in multiple local markets price according to a weighted average of the concentration of the markets in which they operate. The weighted average of the population of each local market in which the bank operates is employed to control for the various differences that may be associated with operating in markets of different size, with no predictions offered regarding the expected coefficient sign. The coefficient of bigshare $_{i}$, measured at the local level, is expected to be negative, based on the hypothesis that a greater presence in the local market of banks that are part of very large organizations (and therefore have access to lower cost wholesale funds) causes other banks in that market to offer lower deposit interest rates. This hypothesis is closely related to one of the predictions of the Park and Pennacchi (2003) model.

Since it is by no means obvious that large multimarket banks price according to the conditions prevailing in the local markets, as traditionally defined, we must also consider the possibility that they price according to competitive interactions that occur in broader geographic areas. Therefore, we examine the role that statewide measures of concentration, population and the presence of large banking organizations play in explaining the deposit pricing of multimarket banks. If multimarket banks perceive competition to be taking place at the statewide level, then the structure-conductperformance paradigm would imply a negative coefficient on the statewide concentration 
measure. Furthermore, state-level competition would suggest that deposit interest rates would be negatively related to the share of statewide branches accounted for by banks that are part of very large banking organizations with access to lower cost sources of funds. Again, no prediction is made regarding the sign of the coefficient on the population variable.

\section{Data}

The data used in this study were obtained from a number of sources, including quarterly Reports of Condition and Income (Call Reports) filed by each depository institution, the Federal Deposit Insurance Corporation's Summary of Deposits (SOD), the Office of Thrift Supervision's Branch Office Survey (BOS), and the Department of Commerce's Regional Accounts Data. Following the previous literature, we define local banking markets as either Metropolitan Statistical Areas (MSAs or urban markets) or nonMSA counties (rural markets). We define a multimarket bank as a bank that reports a positive quantity of deposits in banking offices located in at least three local markets.

We used Call Report information on quarterly interest expenses and end-of-quarter account balances to construct deposit interest rate measures for two types of accounts NOW accounts and savings accounts (including MMDAs). Interest rates were constructed by dividing each bank's quarterly expenses associated with an account type by the average 
of the current and previous quarter's end-of-quarter account balances. ${ }^{4}$ We then calculated the annual interest rate as the annualized geometric mean of the quarterly interest rates.

Observations in the top and bottom percentile were dropped to eliminate outliers.

In recent years, fees have become an important feature of transaction accounts.

Retail customers very likely consider both the interest rate and the fee structure in choosing where to hold their transaction deposits. For this reason, we adjusted the interest rate measures constructed for NOW accounts by subtracting out an annual "fee rate." The "fee rate" was computed in the same manner as the interest rate, substituting service charges on deposit accounts for interest expenses, and including balances in all transaction accounts in the denominator. ${ }^{5}$

Information about the locations of banking offices and the deposits held by each depository institution in each local market were obtained from the SOD (for commercial banks) and the BOS (for thrifts). These data were used to determine the number of local markets in which each bank held deposits and to compute local market and statewide

${ }^{4}$ To eliminate obvious outliers arising from data reporting errors, we deleted any observations for which the reported quarterly interest expenses were negative or the reported end-of-quarter account balances were less than or equal to zero. We also deleted any observation for which current quarter's reported interest expenses were less than $25 \%$ or greater than $400 \%$ of the previous quarter's reported expenses for that type of account, on the assumption that such dramatic changes from one quarter to the next are likely to reflect reporting errors or changes in accounting practices.

${ }^{5}$ Service charges on deposit accounts (fees) are not reported for specific account types, but are primarily associated with transaction accounts. Our "fee rate" therefore reflects an average rate for all types of transaction accounts. In constructing our adjusted interest rate measure for NOW accounts, we are effectively assuming that the "fee rates" for NOW accounts are similar to those on other types of transaction accounts. 
deposit concentration indices. These data were also combined with information from Call Reports to determine the share of each market's (state's) deposits held by banking organizations of various sizes. Data on market and state population were obtained from the Department of Commerce's Regional Accounts Data.

Our sample covers three years, 2000, 2001 and 2002, and includes between 1000 and 1200 multimarket banks each year. Within our sample, the number of markets in which a multimarket bank operates ranges from 3 to over 400, but most banks operate in a only a handful of markets. The median bank in our sample operates in 4 local markets, and three quarters of the banks hold deposits in 6 or fewer markets. The banking organizations represented by our sample banks hold banking assets ranging from around $\$ 20$ million to about $\$ 540$ billion. In each year, between 13 and 16 percent of the sample banks are in organizations with more than $\$ 5$ billion of banking assets, and another 15 to 17 percent are in organizations with banking assets between $\$ 1$ billion and $\$ 5$ billion.

\section{Results}

Table 1 lists the explanatory variables used in the analysis, along with their definitions. Tables 2 through 4 report the results of our various estimations of equation (1). We estimate the equation separately for each of the three sample years, using OLS. Table 2 presents the results of our estimations for the case in which the pricing of the observed multimarket banks is assumed to reflect a weighted average of the characteristics of the local markets in which they operate. The first three columns present results 
obtained for each of the years from 2000 to 2002 using the rate offered on NOW accounts, adjusted for fees, as the dependent variable; the last three columns present results obtained for the same years using the savings account rate (including MMDAs) as the dependent variable.

Note first for all three years examined and for both dependent variables, the coefficients of very_big and big are negative and highly significant, with the magnitude of the coefficient of very_big greater than that of the coefficient of big. These results are consistent with the hypothesis that banks that are part of banking organizations with greater than $\$ 5$ billion in assets (and to a lesser extent, greater than $\$ 1$ billion in assets) have access to cheaper alternative sources of funds, allowing them to be less aggressive in attracting retail deposits.

Note next that the coefficient of the log of the number of local markets in which the bank has offices is also negative and highly significant in every regression. Since this relationship is so pronounced and so consistent across all the years and deposit rates examined, it may be useful to speculate on the reasons for it. One possibility is that, controlling for size, a bank operating in many different markets is better able to specialize in offering a mix of services that particular groups of customers in each market highly value, allowing the bank to offer a lower deposit rate to such customers. This contrasts with a bank of equal size that operates in only one market. Such a bank must obtain deposits from a much broader range of customers, many of whom may not value as highly the particular mix of services that the bank offers, thus requiring that the bank offer higher 
deposit rates to attract such customers.

A competing explanation relates more closely to the argument that access to alternative sources of funds allows large multimarket banks to offer lower retail deposit rates. It is well recognized that geographic diversification can involve less risk on the asset side of the balance sheet, because of greater diversification of default risks. A less risky portfolio may reduce the cost of uninsured wholesale funds, in turn allowing the bank to lower the rates that it offers for retail funds. We cannot distinguish between these, or indeed other, alternative explanations for this finding.

The final three variables represent weighted averages of the characteristics of the local markets in which banks in the sample operate. The variable mktconc denotes the weighted average of the Herfindahl-Hirschmann index of concentration (defined as the sum of squared deposit market shares) of the local markets in which the bank operates, with the weights being the fraction of the bank's deposits held in each local market. The coefficient on this variable is negative, as predicted by the traditional structure-conductperformance hypothesis, in five of the six regressions presented, but it is statistically significant only for the years 2000 and 2001 when the savings deposit rate is used as the dependent variable.

The variable mktpop is the weighted average of local market population in the markets in which the bank operates. The estimated coefficient of this variable is negative in all six cases, and statistically significant in five of them. Thus, operating in more populous local markets appears to be associated with lower deposit rates. 
The variable mktbigshare denotes the weighted average, across markets served by the observed bank, of the share of market branches (excluding the bank's own branches) operated by banks that might be expected to have a funding advantage and therefore offer lower deposit interest rates. ${ }^{6}$ The rationale for this measure is that a greater presence of other banks in each market that offer lower deposit rates because of a funding advantage should, through competitive interactions, imply a lower optimal deposit rate on the part of the observed bank. Park and Pennacchi (2003) derive an implication similar to this from their spatial model of bank pricing behavior. In five out of six cases, the estimated coefficient of mktbigshare has the predicted negative sign, but it is significantly different from zero only for the years 2001 and 2002 when the savings account rate is employed as the dependent variable.

Table 3 presents results of similar regressions, except that the geographic area considered relevant for competition is the state rather than the local market. As in table 2, the estimated coefficients of very_big and big are all negative and statistically significant, with the magnitude of the coefficient of very_big exceeding that of big in each case. Likewise, the estimated coefficient on the log of the number of markets is negative and significantly different from zero in every case. The remaining three explanatory variables are analogous to the weighted average local market variables reported in table 2, except that they are reported for the state rather than the local market. In the few cases in which

6 These are defined as banks that belong to organizations that have at least $\$ 5$ billion in banking assets. The alternative use of $\$ 1$ billion in assets as the relevant threshold yields similar results. 
the multimarket bank operates in more than one state, these variables are calculated as a weighted average of the characteristics of the states in which the multistate bank operates, with the fraction of the bank's deposits held in each state serving as the weights.

The coefficients of the Herfindahl-Hirschmann index of concentration, denoted stconc, are negative and statistically significant in all six reported regressions. These results appear to suggest that, for the multimarket banks that are the focus of this study, state level measures of concentration perform better in explaining cross-sectional variations in deposit interest rates than do weighted average measures of local market concentration.

The coefficients of state population, denoted stpop, are negative and statistically significant in four of the six regressions reported. This is similar to the negative and statistically significant coefficients of local market population reported in table 2 . The branch share of other banks in the state that might enjoy a funding advantage (defined as banks that belong to banking organizations with more than $\$ 5$ billion in assets) has the expected negative sign in only two out of six cases, and is marginally significant in one of those two.

Table 4 reports results of regressions that are similar to those reported in tables 2 and 3, except that the variables intended to capture the characteristics of the local market and the state are included together, in order to further explore the relevance of these different geographical areas to the setting of deposit interest rates. As in tables 2 and 3, the estimated coefficients of very_big, big, and $\ln ($ nummkt) are negative and statistically 
significant in each regression. In comparing the coefficients of the measures of concentration calculated for the local and state levels, the coefficient of mktconc is negative in five out of six cases, and significantly different from zero in only one case. The coefficient of stconc is negative in all six reported regressions and statistically significant in four of them.

Coefficients of local market population (mktpop) are negative in all six cases, but significantly different from zero only for the three cases where the NOW account interest rate is the dependent variable. In contrast, the coefficient of state population (stpop) is statistically insignificant in all three cases where the NOW account interest rate is the dependent variable (and positive in two of those three cases); but it is negative and significantly different from zero in all three cases where the savings account interest rate is the dependent variable. This might suggest that competition for NOW accounts is more geographically limited than for savings accounts; however, the coefficients of the other geographically based variables do not tell the same story.

The variables designed to measure the importance of large competing banks that might have a funding advantage are statistically insignificant, except for the state level variable in the equation explaining savings accounts deposit interest rates for 2000.

\section{Conclusion}

Increasingly, large banking organizations in the U.S. are spreading out over a larger number of the areas typically defined as local banking markets in regulatory 
analyses, obtaining smaller and smaller proportions of their deposits from any one local area. Also, there is substantial evidence that such banks offer the same deposit rates in many of the local areas in which they operate. Additionally, a number of researchers have suggested that larger banks have greater access to alternative and (beyond some point) cheaper sources of funds, implying, under some circumstances, optimally lower retail deposit interest rates (and lower loan rates as well). In this paper, we seek to explain the deposit interest rates offered by large multimarket banks in a way that takes into account these considerations.

We find strong evidence that large banks, or banks that are part of large banking organizations, offer lower deposit interest rates than their smaller counterparts. This finding is consistent with the hypothesis that such banking organizations enjoy a funding advantage relative to smaller banking organizations. We also find strong evidence that, all else equal (including asset size of the organization), banks that operate in a larger number of local banking markets offer lower deposit interest rates. We speculate that this may be due to a diversification benefit that reduces the cost of wholesale sources of funds or to the ability of banks with a presence in many local areas to serve only those retail customers for whom the bank's mix of services is particularly desirable.

For banks that operate in many local banking markets but nonetheless offer the same deposit rate in each of them, it is natural to speculate that the bank's uniform price reflects some weighted average of the conditions in the local markets in which it operates. Although we find some evidence that weighted average market characteristics are 
significantly related to the deposit interest rates offered by multimarket banks, the evidence in favor of this view is, on the whole, not strong. Indeed, in the case of market structure, concentration measured at the state level appears to be more strongly and consistently related to the deposit interest rates offered by multimarket banks than is a weighted average of local market concentration. This finding suggests that multimarket banks may view the state, rather than the local market, as the geographic area over which they compete for retail deposits.

This result, together with the findings of other recent research, raises some interesting questions regarding the definition of geographic markets in the antitrust analysis of bank mergers and acquisitions. Hannan and Prager (forthcoming) find a strong link between local market concentration and the deposit interest rates offered by singlemarket banks, even in the presence of competition from multimarket firms. Heitfield and Prager (2004) examine the deposit interest rates offered by a large sample of banks, including both single-market and multimarket firms, in each of four years, 1988, 1992, 1996 and 1999. They find no evidence of a weakening of the relationship between local market concentration and deposit interest rates over time, but do find an increasingly strong link between statewide measures of concentration and deposit interest rates. Their results are consistent with (i) the findings of Hannan and Prager (forthcoming) that local market conditions still matter for the large number of single-market banks operating in the U.S.; (ii) the findings of the present paper that statewide conditions may be more relevant for multimarket banks; and (iii) the observation that multimarket banks have been growing 
in importance over time. Together, these research findings suggest that defining the appropriate scope of the geographic markets to be used in analyzing the likely competitive effects of proposed bank mergers may be more complex than has been recognized to date. Further research will be needed before the antitrust authorities can fully appreciate the policy implications of recent changes in the U.S. banking industry.

Finally, we also examine whether competition from large banking organizations, which presumably enjoy a funding advantage, causes other banks to offer lower deposit interest rates. We do not find convincing evidence consistent with this hypothesis, regardless of whether competition is assumed to take place at the local or statewide level. 


\section{References}

Biehl, Andrew. "The Extent of the Market for Retail Banking Deposits," Antitrust Bulletin 47 (2002), pp. 91-106.

Hannan, Timothy H. and Robin A. Prager. "The Competitive Implications of Multimarket Bank Branching," Journal of Banking and Finance (forthcoming,).

Heitfield, Erik A. "What Do Interest Rate Data Say About the Geography of Retail Banking Markets?" Antitrust Bulletin 44 (1999), pp. 333-347.

Heitfield, Erik A. and Robin A. Prager. "The Geographic Scope of Retail Deposit Markets," Journal of Financial Services Research 25 (2004), pp. 37-55.

Kiser, Elizabeth K. "Modeling the Whole Firm: The Effect of Multiple Inputs and Financial Intermediation on Bank Deposit Rates," FEDS Working Paper No. 2004-07, Federal Reserve Board (2004).

Park, Kwangwoo, and George Pennacchi. "Harming Depositors and Helping Borrowers: The Disparate Impact of Bank Consolidation,” unpublished manuscript (2003).

Radecki, Lawrence J. "The Expanding Geographic Reach of Retail Banking Markets," Economic Policy Review 4 (2), Federal Reserve Bank of New York, (1998) pp. 15-34. 
Table 1

Variable Definitions

\begin{tabular}{|c|c|}
\hline big & $\begin{array}{l}\text { A dummy variable receiving the value of one if the bank belongs to an } \\
\text { organization with more than } \$ 1 \text { billion and less than } \$ 5 \text { billion in banking } \\
\text { assets, and zero otherwise. }\end{array}$ \\
\hline very_big & $\begin{array}{l}\text { A dummy variable receiving the value of one if the bank belongs to an } \\
\text { organization with } \$ 5 \text { billion or more in banking assets, and zero otherwise. }\end{array}$ \\
\hline $\ln \left(n u m \_m k t\right)$ & Natural log of the number of local markets in which the bank has offices. \\
\hline mktconc & $\begin{array}{l}\text { Weighted average of the Herfindahl-Hirschmann index of concentration } \\
\text { (defined as the sum of squared deposit market shares) of the local markets } \\
\text { in which the bank operates, with the fraction of the bank's deposits held in } \\
\text { each local market serving as the weights. }\end{array}$ \\
\hline mktpop & $\begin{array}{l}\text { Natural logarithm of the weighted average of the population of the local } \\
\text { markets in which the bank operates, with the fraction of the bank's deposits } \\
\text { held in each local market serving as the weights. }\end{array}$ \\
\hline mktbigshare & $\begin{array}{l}\text { Weighted average of the share of other banks' branches in the local market } \\
\text { that are accounted for by banks that belong to organizations with at least } \$ 5 \\
\text { billion in assets, with the fraction of the bank's deposits held in each local } \\
\text { market serving as the weights }\end{array}$ \\
\hline stconc & $\begin{array}{l}\text { The Herfindahl-Hirschmann index of concentration calculated for the state } \\
\text { in which the bank operates. (A weighted average of state concentration is } \\
\text { employed in the case of banks that operate in more than one state, with } \\
\text { state deposit shares serving as the weights.) }\end{array}$ \\
\hline stpop & $\begin{array}{l}\text { The natural logarithm of the population of the state in which the bank } \\
\text { operates }\end{array}$ \\
\hline stbigshare & $\begin{array}{l}\text { The share of other banks' branches in the state that are accounted for by } \\
\text { banks that belong to organizations with at least } \$ 5 \text { billion in assets. }\end{array}$ \\
\hline
\end{tabular}


Table 2

OLS Regressions Explaining Retail Deposit Rates Offered by Multimarket Banks, with Geographically Based Explanatory Variables Measured at the Local Market Level

\begin{tabular}{|c|c|c|c|c|c|c|}
\hline Year & 2000 & 2001 & 2002 & 2000 & 2001 & 2002 \\
\hline $\begin{array}{l}\text { Dependent } \\
\text { Variable } \\
\end{array}$ & \multicolumn{3}{|c|}{ NOW Account Rates (Adjusted for Fees) } & \multicolumn{3}{|c|}{ Savings Account Rates (Including MMDAs) } \\
\hline Intercept & $\begin{array}{c}2.57 \\
(4.45)\end{array}$ & $\begin{array}{c}2.18 \\
(3.69)\end{array}$ & $\begin{array}{c}1.76 \\
(2.61)\end{array}$ & $\begin{array}{c}4.47 \\
(15.90)\end{array}$ & $\begin{array}{c}3.56 \\
(17.95)\end{array}$ & $\begin{array}{c}1.98 \\
(13.61)\end{array}$ \\
\hline big & $\begin{array}{c}-.40 * \\
(-2.38)\end{array}$ & $\begin{array}{c}-.72 * * \\
(-4.23)\end{array}$ & $\begin{array}{l}-1.02 * * \\
(-5.12)\end{array}$ & $\begin{array}{c}-.22 * * \\
(-2.86)\end{array}$ & $\begin{array}{c}-.28 * * \\
(-5.17)\end{array}$ & $\begin{array}{c}-.29 * * \\
(-7.03)\end{array}$ \\
\hline very_big & $\begin{array}{l}-1.50 * * \\
(-7.07)\end{array}$ & $\begin{array}{l}-2.01 * * \\
(-8.52)\end{array}$ & $\begin{array}{l}-2.12 * * \\
(-8.10)\end{array}$ & $\begin{array}{l}-.39 * * \\
(-4.34)\end{array}$ & $\begin{array}{l}-.44 * * \\
(-6.14)\end{array}$ & $\begin{array}{c}-.39 * * \\
(-7.67)\end{array}$ \\
\hline $\ln ($ num_mkt $)$ & $\begin{array}{l}-.44 * * \\
(-4.42)\end{array}$ & $\begin{array}{c}-.52 * * \\
(-4.97)\end{array}$ & $\begin{array}{l}-.81 * * \\
(-7.26)\end{array}$ & $\begin{array}{c}-.055 \\
(-1.28)\end{array}$ & $\begin{array}{c}-.077^{*} \\
(-2.37)\end{array}$ & $\begin{array}{l}-.074 * * \\
(-3.25)\end{array}$ \\
\hline mktconc & $\begin{array}{c}.018 \\
(.03)\end{array}$ & $\begin{array}{c}-.37 \\
(-.66)\end{array}$ & $\begin{array}{c}-.53 \\
(-.84)\end{array}$ & $\begin{array}{l}-.82 * * \\
(-3.02)\end{array}$ & $\begin{array}{l}-.69 * * \\
(-3.60)\end{array}$ & $\begin{array}{c}-.17 \\
(-1.24)\end{array}$ \\
\hline mktpop & $\begin{array}{l}-.14^{* *} \\
(-3.15)\end{array}$ & $\begin{array}{l}-.16^{* *} \\
(-3.33)\end{array}$ & $\begin{array}{l}-.16^{* *} \\
(-2.99)\end{array}$ & $\begin{array}{c}-.054 * \\
(-2.46)\end{array}$ & $\begin{array}{c}-.038^{*} \\
(-2.40)\end{array}$ & $\begin{array}{r}-.014 \\
(-1.22)\end{array}$ \\
\hline mktbigshare & $\begin{array}{c}-.30 \\
(-1.07)\end{array}$ & $\begin{array}{l}-.079 \\
(-.27)\end{array}$ & $\begin{array}{l}.16 \\
(.46)\end{array}$ & $\begin{array}{c}-.19 \\
(-1.39)\end{array}$ & $\begin{array}{l}-.29 * * \\
(-2.98)\end{array}$ & $\begin{array}{c}-.16^{*} \\
(-2.17)\end{array}$ \\
\hline $\mathrm{N}$ & 893 & 940 & 981 & 1,016 & 1,085 & 1,152 \\
\hline $\mathrm{R}^{2}$ & .24 & .28 & .30 & .083 & .16 & .19 \\
\hline
\end{tabular}

t-statistics in parentheses.

,$+ *$, and $* *$ indicate statistical significance at the 0.10 .0 .05 and 0.01 levels, respectively. 
Table 3

OLS Regressions Explaining Retail Deposit Rates Offered by Multimarket Banks, with Geographically Based Explanatory Variables Defined at the State Level

\begin{tabular}{|c|c|c|c|c|c|c|}
\hline Year & 2000 & 2001 & 2002 & 2000 & 2001 & 2002 \\
\hline $\begin{array}{l}\text { Dependent } \\
\text { Variable }\end{array}$ & \multicolumn{3}{|c|}{ NOW Account Rates (Adjusted for Fees) } & \multicolumn{3}{|c|}{ Savings Account Rates (Including MMDAs) } \\
\hline Intercept & $\begin{array}{c}3.09 \\
(2.90)\end{array}$ & $\begin{array}{c}.82 \\
(.74)\end{array}$ & $\begin{array}{l}1.09 \\
(.84)\end{array}$ & $\begin{array}{c}5.56 \\
(11.19)\end{array}$ & $\begin{array}{c}4.13 \\
(11.18)\end{array}$ & $\begin{array}{c}2.61 \\
(9.42)\end{array}$ \\
\hline big & $\begin{array}{c}-.53 * * \\
(-3.27)\end{array}$ & $\begin{array}{c}-.90 * * \\
(-5.45)\end{array}$ & $\begin{array}{l}-1.16^{* * *} \\
(-5.97)\end{array}$ & $\begin{array}{c}-.19 * \\
(-2.62)\end{array}$ & $\begin{array}{c}-.29 * * \\
(-5.61)\end{array}$ & $\begin{array}{c}-.29 * * \\
(-7.47)\end{array}$ \\
\hline very_big & $\begin{array}{l}-1.72 * * \\
(-8.47)\end{array}$ & $\begin{array}{l}-2.23 * * \\
(-9.76)\end{array}$ & $\begin{array}{l}-2.30 * * \\
(-9.02)\end{array}$ & $\begin{array}{l}-.39 * * \\
(-4.66)\end{array}$ & $\begin{array}{c}-.45 * * \\
(-6.63)\end{array}$ & $\begin{array}{c}-.39 * * \\
(-8.10)\end{array}$ \\
\hline $\ln \left(n u m \_m k t\right)$ & $\begin{array}{c}-.48 * * \\
(-4.77)\end{array}$ & $\begin{array}{c}-.55^{* *} \\
(-5.27)\end{array}$ & $\begin{array}{c}-.85^{* *} \\
(-7.58)\end{array}$ & $\begin{array}{c}-.083+ \\
(-1.96)\end{array}$ & $\begin{array}{l}-.099 * * \\
(-3.07)\end{array}$ & $\begin{array}{l}-.084 * * \\
(-3.73)\end{array}$ \\
\hline stconc & $\begin{array}{l}-4.01 * * \\
(-3.43)\end{array}$ & $\begin{array}{c}-2.58^{*} \\
(-2.25)\end{array}$ & $\begin{array}{c}-2.48+ \\
(-1.76)\end{array}$ & $\begin{array}{l}-1.64 * * \\
(-2.96)\end{array}$ & $\begin{array}{l}-1.34 * * \\
(-3.73)\end{array}$ & $\begin{array}{c}-.88 * * \\
(-3.07)\end{array}$ \\
\hline stpop & $\begin{array}{c}-.13+ \\
(-1.74)\end{array}$ & $\begin{array}{l}-.021 \\
(-.27)\end{array}$ & $\begin{array}{c}-.078 \\
(-.87)\end{array}$ & $\begin{array}{l}-.10^{* *} \\
(-3.11)\end{array}$ & $\begin{array}{c}-.067^{*} \\
(-2.66)\end{array}$ & $\begin{array}{l}-.053 * * \\
(-2.76)\end{array}$ \\
\hline stbigshare & $\begin{array}{l}.24 \\
(.51)\end{array}$ & $\begin{array}{c}.10 \\
(.22)\end{array}$ & $\begin{array}{l}.45 \\
(.78)\end{array}$ & $\begin{array}{c}-.41+ \\
(-1.90)\end{array}$ & $\begin{array}{c}-.22 \\
(-1.42)\end{array}$ & $\begin{array}{c}.019 \\
(.15)\end{array}$ \\
\hline $\mathrm{N}$ & 893 & 940 & 981 & 1,016 & 1,085 & 1,152 \\
\hline $\mathrm{R}^{2}$ & .24 & .27 & .29 & .12 & .18 & .20 \\
\hline
\end{tabular}

$\mathrm{t}$-statistics in parentheses.

,$+ *$, and $* *$ indicate statistical significance at the 0.10 .0 .05 and 0.01 levels, respectively. 
Table 4

OLS Regressions Explaining Retail Deposit Rates Offered by Multimarket Banks, with Both State and Local Market Variables Included

\begin{tabular}{|c|c|c|c|c|c|c|}
\hline Year & 2000 & 2001 & 2002 & 2000 & 2001 & 2002 \\
\hline $\begin{array}{l}\text { Dependent } \\
\text { Variable }\end{array}$ & \multicolumn{3}{|c|}{ NOW Account Rates (Adjusted for Fees) } & \multicolumn{3}{|c|}{ Savings Account Rates (Including MMDAs) } \\
\hline Intercept & $\begin{array}{c}2.90 \\
(2.48)\end{array}$ & $\begin{array}{l}1.06 \\
(.87)\end{array}$ & $\begin{array}{c}1.51 \\
(1.08)\end{array}$ & $\begin{array}{c}5.77 \\
(10.58)\end{array}$ & $\begin{array}{c}4.55 \\
(11.31)\end{array}$ & $\begin{array}{c}2.73 \\
(9.12)\end{array}$ \\
\hline big & $\begin{array}{c}-.39 * \\
(-2.33)\end{array}$ & $\begin{array}{l}-.71 * * \\
(-4.16)\end{array}$ & $\begin{array}{l}-1.012^{* *} \\
(-5.08)\end{array}$ & $\begin{array}{c}-.23 * * \\
(-3.06)\end{array}$ & $\begin{array}{c}-.29 * * \\
(-5.35)\end{array}$ & $\begin{array}{c}-.29 * * \\
(-7.09)\end{array}$ \\
\hline very_big & $\begin{array}{l}-1.46^{* *} \\
(-6.85)\end{array}$ & $\begin{array}{l}-1.93 * * \\
(-8.14)\end{array}$ & $\begin{array}{l}-2.06 * * \\
(-7.80)\end{array}$ & $\begin{array}{c}-.45 * * \\
(-5.03)\end{array}$ & $\begin{array}{c}-.46^{* * *} \\
(-6.33)\end{array}$ & $\begin{array}{c}-.39 * * \\
(-7.67)\end{array}$ \\
\hline $\ln ($ num_mkt) & $\begin{array}{c}-.46^{* * *} \\
(-4.60)\end{array}$ & $\begin{array}{c}-.52 * * \\
(-4.96)\end{array}$ & $\begin{array}{c}-.81 * * \\
(-7.19)\end{array}$ & $\begin{array}{c}-.084^{*} \\
(-1.98)\end{array}$ & $\begin{array}{l}-.093 * * \\
(-2.89)\end{array}$ & $\begin{array}{c}-.083 * * \\
(-3.64)\end{array}$ \\
\hline mktconc & $\begin{array}{c}.46 \\
(.80)\end{array}$ & $\begin{array}{c}-.11 \\
(-.18)\end{array}$ & $\begin{array}{c}-.43 \\
(-.66)\end{array}$ & $\begin{array}{c}-.47 \\
(-1.64)\end{array}$ & $\begin{array}{r}-.51^{*} \\
(-2.55)\end{array}$ & $\begin{array}{c}-.085 \\
(-.58)\end{array}$ \\
\hline mktpop & $\begin{array}{c}-.11 * \\
(-2.19)\end{array}$ & $\begin{array}{c}-.16^{* *} \\
(-3.24)\end{array}$ & $\begin{array}{c}-.16^{* * *} \\
(-2.77)\end{array}$ & $\begin{array}{l}-.0031 \\
(-.13)\end{array}$ & $\begin{array}{l}-.0093 \\
(-.54)\end{array}$ & $\begin{array}{l}-.0045 \\
(-.35)\end{array}$ \\
\hline mktbigshare & $\begin{array}{c}-.34 \\
(-.91)\end{array}$ & $\begin{array}{l}-.11 \\
(-.27)\end{array}$ & $\begin{array}{l}-.0015 \\
(-.00)\end{array}$ & $\begin{array}{c}.29 \\
(1.60)\end{array}$ & $\begin{array}{c}-.13 \\
(-.94)\end{array}$ & $\begin{array}{c}-.14 \\
(-1.43)\end{array}$ \\
\hline stconc & $\begin{array}{l}-3.36 * * \\
(-2.72)\end{array}$ & $\begin{array}{c}-1.61 \\
(-1.36)\end{array}$ & $\begin{array}{l}-1.39 \\
(-.95)\end{array}$ & $\begin{array}{c}-1.50^{*} \\
(-2.54)\end{array}$ & $\begin{array}{l}-1.16 * * \\
(-3.08)\end{array}$ & $\begin{array}{c}-.87^{* *} \\
(-2.88)\end{array}$ \\
\hline stpop & $\begin{array}{l}-.052 \\
(-.64)\end{array}$ & $\begin{array}{r}.073 \\
(.85)\end{array}$ & $\begin{array}{l}.0079 \\
(.08)\end{array}$ & $\begin{array}{c}-.11 * * \\
(-2.79)\end{array}$ & $\begin{array}{l}-.081^{* *} \\
(-2.84)\end{array}$ & $\begin{array}{l}-.063^{* *} \\
(-2.93)\end{array}$ \\
\hline stbigshare & $\begin{array}{c}.68 \\
(1.16)\end{array}$ & $\begin{array}{c}.37 \\
(.60)\end{array}$ & $\begin{array}{c}.62 \\
(.87)\end{array}$ & $\begin{array}{r}-.70^{*} \\
(-2.51)\end{array}$ & $\begin{array}{l}-.083 \\
(-.41)\end{array}$ & $\begin{array}{c}-.14 \\
(-1.43)\end{array}$ \\
\hline $\mathrm{N}$ & 893 & 940 & 981 & 1,016 & 1,085 & 1,152 \\
\hline $\mathrm{R}^{2}$ & .25 & .29 & .30 & .12 & .18 & .20 \\
\hline
\end{tabular}

t-statistics in parentheses.

,$+ *$, and $* *$ indicate statistical significance at the 0.10 .0 .05 and 0.01 levels, respectively. 